\title{
Nitrogen fertilization for wheat growing in dual purpose integrated system of agricultural production
}

\section{Adubação nitrogenada em cobertura para produção de trigo duplo propósito em sistema Integrago de Produção Agropecuária}

\author{
Éderson Luis Henz ${ }^{*}$; Paulo Sergio Gois Almeida²; João Pedro Velho²; \\ José Laerte Nörnberg ${ }^{3}$; Leandro das Dores Ferreira da Silva \\ Fernando Luiz Massaro Junior ${ }^{5}$; Geisi Loures Guerra ${ }^{6}$
}

\begin{abstract}
Nowadays, there are numerous arrangements of Integrated Systems of Agricultural Production, due, the particularities of each region and/or rural enterprise. The use of dual-purpose species such as, for example, BRS Tarumã ${ }^{\circledR}$ wheat further intensifies the system, because there is plant-animal production in a short time. Study aimed to evaluate the production and chemical composition of dual purpose wheat pastures managed with different DAN during periods of spikelet terminal (ST) and anthesis (AN), aiming crop production (pasture and grain) and animal (milk and / or meat). The experimental randomized block design with five treatments $\left(0,75,150,225\right.$ e $300 \mathrm{Kg} \mathrm{de} \mathrm{N} \mathrm{ha}^{-1}$, in the form of ammonium nitrate) and four replications. The average biomass values before the first and the second grazing were respectively: 2,164 and 2,127 kg DM per hectare and the waste of about 824 and 1,772 $\mathrm{kg}$ of DM per hectare and the daily average accumulation rate between the two grazing DM was $86 \mathrm{~kg}$ per hectare at 17 day intervals. The variables, number of spikes per square meter, grain number per square meter, thousand grain weight, hectoliter weight and grain yield did not differ $(\mathrm{P}>0.05)$ between treatments. Nitrogen fertilization increases linearly $(\mathrm{P}=0.0017)$ the size of the spikes depending on nitrogen rates. For the linear variable layering increased $(\mathrm{P}=0.0001)$, indicating the susceptibility of the crop to high levels of nitrogen. The application of nitrogen fertilizer levels in dual purpose grazed wheat before the spikelet terminal stage and anthesis does not influence on grain yield variables. The nitrogen fertilization on wheat double purpose must be fractionated at tillering and after each grazing increasing the remobilization rate of nitrogen by culture.
\end{abstract}

Key words: Meat. Fertility. Grain. Crop-livestock integration. Milk. Pasture.

\section{Resumo}

Atualmente, há inúmeros arranjos de Sistemas Integrados de Produção Agropecuária, em função, das particularidades de cada região e/ou empresa rural. A utilização de espécies de duplo propósito como,

\footnotetext{
${ }^{1}$ Discente do Curso de Mestrado do Programa de Pós-Graduação em Ciência Animal, Universidade Estadual de Londrina, UEL, Londrina, PR, Brasil. E-mail: ederhenz@gmail.com

2 Profs. Adjuntos, Departamento de Zootecnia e Ciências Biológicas, Campus de Palmeira das Missões, Universidade Federal de Santa Maria, UFSM, Palmeira das Missões, RS, Brasil. E-mail: pauloalmeida@smail.ufsm.br; velhojp@ufsm.br

3 Prof. Associado, Departamento de Tecnologia e Ciência dos Alimentos, UFSM, Campus de Santa Maria, Santa Maria, RS, Brasil. E-mail: jlnornberg@gmail.com

4 Prof. Dr. Associado, Departamento de Zootecnia, UEL, Londrina, PR, Brasil. E-mail: leandro@uel.br

5 Dr., Programa de Pós-Graduação em Ciência Animal, UEL, Londrina, PR. E-mail: massaro@uel.br

${ }^{6}$ Discente do Curso de Doutorado do Programa de Pós-Graduação em Ciência Animal, UEL, Londrina PR, Brasil. E-mail: geisi_ guerra@hotmail.com

* Author for correspondence
} 
por exemplo, o trigo BRS Tarumã ${ }^{\circledR}$ intensifica ainda mais o sistema, pois há produção vegetal-animal em curto espaço de tempo. Objetivou-se avaliar a produção e a composição bromatológica de pastagens de trigo duplo propósito manejadas com diferentes DAN nos períodos de espigueta terminal (ET) e antese (AN), almejando produção vegetal (pastagem e grão) e animal (leite e/ou carne). Utilizou-se delineamento experimental de blocos casualizados com cinco tratamentos $(0,75,150,225$ e $300 \mathrm{Kg}$ de $\mathrm{N} \mathrm{ha}^{-1}$, sob a forma de nitrato de amônia) e quatro repetições. Os valores médios de biomassa antes do primeiro e do segundo pastejo foram respectivam ente de: 2.164 e $2.127 \mathrm{Kg}$ de MS por hectare e os resíduos da ordem de 824 e $1.772 \mathrm{Kg}$ de MS por hectare e a taxa de acúmulo diária média entre os dois pastejos foi $86 \mathrm{Kg}$ de MS por hectare em 17 dias de intervalo. As variáveis número de espigas por metro quadrado, número de grão por metro quadrado, peso de mil grãos, peso do hectolitro e produção de grãos não diferiram $(\mathrm{P}>0,05)$ entre os tratamentos. A adubação nitrogenada aumentou linearmente $(\mathrm{P}=0,0017)$ o tamanho das espigas, em função das doses de nitrogênio. Para a variável acamamento houve aumentou linear $(\mathrm{P}=0,0001)$, evidenciando a susceptibilidade da cultura para elevadas doses de nitrogênio. A aplicação de doses de adubação nitrogenada em trigo duplo propósito pastejado antes dos estádios de espigueta terminal e antese não influencia nas variáveis de rendimento de grão. A adubação nitrogenada em trigo duplo propósito deve ser fracionada no perfilhamento e após cada pastejo aumentando a taxa de remobilização do nitrogênio pela cultura.

Palavras-chave: Carne. Fertilidade. Grão. Integração lavoura-pecuária. Leite. Pastagem.

\section{Introduction}

Nowadays, there are numerous arrangements of Integrated Systems of Agricultural Production, due, the particularities of each region and/or rural enterprise, whose systems have been considered of fundamental importance to food security globally (CARVALHO et al., 2014). The use of dual-purpose species such as, for example, BRS Tarumã ${ }^{\circledR}$ wheat further enhances the system, because the plantanimal production (pasture for the production of meat, milk and/or wool) and plant (wheat grain) occurs in the same crop, i.e. after the removal of grazing animals harvesting crops occurs on average between 80-120 days. Therefore, the nutrient requirements of a wheat plant intended for the dual purpose should be different when compared to the cultivation strictly grains.

The fertilizer recommendations for wheat production in the southern region are based exclusively to grains. However, the cultivation of wheat dual-purpose (WDP) is differentiated, because before reaching the peak of its production (grain) is subjected to defoliation of different intensities (supply of pasture, cargo and animals category) and frequency (number of system and grazing), but regardless of the degree, it is a stress for dual purpose plant by which cultivars that produce only wheat does not pass. Thus, it is assumed that the WDP grazing should receive higher doses of nitrogen fertilization, in order to stimulate the regrowth and not reduce grain production.

In a study conducted evaluating pastures in croplivestock integration system Soussana and Lemaire (2014) concluded that interactions between soilvegetation (grass) allow synchronization between the carbon and nitrogen cycles, reducing nitrogen losses to the atmosphere and hydrosphere and increasing net primary production of carbon in the soil by the increased production of roots and leaves.

According to Rodrigues et al. (2011), nitrogen application should be split between sowing to optimize the initial growth and coverage. In applying coverage, the dose may also be divided between the stages spikelet terminal (ST) and anthesis (AN). In the case of application in a single dose ST stage is preferred, as the requirement for nitrogen after this stage is maximum, and determines a larger number of fertile flowers (flower that will establish grains) and consequently high yield. This study aimed to evaluate the production and chemical composition of wheat pasture dual purpose handled with different DAN in the ST and AN stages in aiming cover crop 
production (pasture and grain) and animal (milk and/or meat).

\section{Material and Methods}

The study was conducted at Librelotto Farm in Boa Vista das Missoes - RS. The soil is classified as Dystrophic Red typical, $600 \mathrm{~g} \mathrm{~kg}^{-1}$ of clay level, deep and well drained. At the beginning of the experiment we found that the soil contained: $\mathrm{pH}$ $(\mathrm{H} 2 \mathrm{O})=5.6 ; \mathrm{P}=7.1 \mathrm{mg} \mathrm{dm}{ }^{3} ; \mathrm{K}=121 \mathrm{mg} \mathrm{dm}^{3}$; $\mathrm{M} . \mathrm{O}=3.5 \% ; \mathrm{Al}=0.0 \mathrm{cmol} \mathrm{dm}^{3} ; \mathrm{Ca}=5.9 \mathrm{cmol} \mathrm{dm}^{3}$; $\mathrm{Mg}=3.2 \mathrm{cmol} \mathrm{dm}^{3} ; \mathrm{CTC}=13.8 \mathrm{cmol} \mathrm{dm}^{3} ; \mathrm{SB}=$ $68 \%$. It was used a randomized experimental blocks with five treatments $(0,75,150,225$ and $300 \mathrm{Kg}$ of $\mathrm{N} \mathrm{ha}^{-1}$, in the form of ammonium nitrate, applied in coverage) and four replications, each plot was $36 \mathrm{~m}^{2}$ $(9 \mathrm{x} 4 \mathrm{~m})$.

The cultivation of the dual purpose BRS Taruma ${ }^{\circledR}$ wheat was preceded by two grasses: maize (Zea mays) normal times for yield and then millet (Pennisetum americanum) which was used for grazing. All cultures performed at Librelotto Farm are performed as the premises of Direct Planting System in straw, in level and use of terraces, i.e. as the recommended techniques for the conservation of soil fertility in function, the use of Integrated Agricultural Production System. The sowing was performed using (140 Kg of viable seeds $\mathrm{ha}^{-1}$ ) the second fortnight of April 2012. Basic fertilization was carried out by using $300 \mathrm{~kg} \mathrm{ha}^{-1}$ formulated 10 20-10 (N-P $\left.\mathrm{O}_{5}-\mathrm{K}_{2} \mathrm{O}\right)$.

At first it was set $100 \mathrm{~kg} \mathrm{~N} \mathrm{ha-1} \mathrm{following}$ recommendations of the South-Brazilian Commission of Wheat Research (CSBPT, 2004) in the vegetative stage of culture divided into three stages (first third 27 days after sowing (DAS); second third 70 DAS what happened after the 1st grazing; 87 DAS in the last third, or shortly after the 2nd grazing). After their last grazing (97 DAS) doses of $\mathrm{N}$ were applied, period between the initiation of spikelet terminal (ST) and anthesis (AN). Both pasturing occurred during eight hours
(7:30 - 15: 30h), using 25 Holstein cows owned by Busanello family with a live weight of $650 \mathrm{~kg}$ so that the instantaneous stocking rate was $225,000 \mathrm{~kg}$ live weight per hectare.

The measurement of available biomass per hectare was held one day before the pasturing and soon after that the waste was determined, using square of $0.25 \mathrm{~m}^{2}$, and cutting plants close to the ground, then they were weighed to get the green matter. Subsequently, they were pre-dried in an air forced circulation stove for 72 hours at $55^{\circ} \mathrm{C}$.

It was evaluated: dry matter production (DMP), daily accumulation rate (DAR), estimated pasture consumption, residue after grazing, Nitrogen use efficiency (NUE) in the plant according to the procedures described by Lupatini et al. (1998), grain production (GP), hectoliter weight (HW), spike length (SL), number of grains per spike (NGS) and percentage of layering (PL). The residual straw was assessed on the day of harvest of the grains.

After determining the partially dry matter content, the grinding was held in a Wiley mill with sieve of a millimeter. It was determined the contents of dry matter (DM), mineral matter (MM), ether extract (EE), crude protein $(\mathrm{CP})$, neutral detergent insoluble protein (NDIP) and acid (ADIP), neutral detergent fiber (NDFcp) and acid (ADFcp) corrected for ash and protein, acid detergent lignin (ADL), cellulose (CEL) and hemicellulose (HEM), according to the procedures described by Silva and Queiroz (2002). Posteriorly, total carbohydrates were estimated CHOT $(\% \mathrm{DM})=100-[\mathrm{CP}(\% \mathrm{DM})+\mathrm{EE}(\% \mathrm{DM})$ $+\mathrm{MM}(\% \mathrm{DM})]$, non-fibrous carbohydrates NFC $(\% \mathrm{DM})=\mathrm{CHOT}(\% \mathrm{DM})-\mathrm{NDF}(\% \mathrm{DM})$ according to Sniffen et al. (1992).

Two fungicide applications were performed, 250 mL.ha- ${ }^{-1}$ of Azoxystrobin and $250 \mathrm{~mL} \cdot \mathrm{ha}^{-1}$ of Ciproconazole by applying, with the first dose at 117 DAS and the second dose at 142 DAS. The harvest of grains occurred at 218 DAS. The results were submitted to regression analysis, using SAS software version 8.2 (SAS, 2001). 


\section{Results and Discussion}

The average biomass values before the first and the second grazing were respectively: 2,164 and $2,127 \mathrm{~kg}$ of DM per hectare and the residues of about 824 and $1,772 \mathrm{~kg}$ of DM per hectare and DAR average of the two grazing was $86 \mathrm{~kg}$ of DM per hectare at 17 day intervals. The result clarifies that, although DAR defoliation be a stress factor for the plant (1st grazing), it stimulates the regrowth, so that the grazing provides greater production of organic matter per hectare, capturing more carbon into the system as verified by Soussana and Lemaire (2014). In a study conducted in the Central Depression of Rio Grande do Sul Meinerz et al. (2012) have obtained daily accumulation rate for the BRS Tarumã ${ }^{\circledR}$ of $42 \mathrm{~kg}$ DM per day, with $100 \%$ growth was as leaf lamina.

It is emphasized that the regrowth capacity of BRS Tarumã ${ }^{\circledR}$ provided new grazing in a few days (17) with high instantaneous stocking rate $\left(225,000 \mathrm{~kg} \mathrm{ha}^{-1}\right)$ in an intermittent grazing system and conjugate the concentration of nutrients in the pasture (Table 1), whose DM, CHOT, NDF, NDFcp, ADFcp and CP favor the rumen fermentation and consequently animal performance. However it is noted that the cuts be made close to the ground to measure the biomass available, as well as to collect samples for Bromatological analysis, and considering that cows do not graze so low it is emphasized that the quality of ingested food was even greater than that specified in Table 1. In a review of the importance of the bit precision grazing Carvalho et al. (2009) consider that effective bits linked to bit rate make the ruminant become an environmental engineer, because it converts food unsuitable for human consumption in high biological value food.

Table 1. Average levels of the chemical composition of dual-purpose wheat pasture.

\begin{tabular}{lc}
\hline Parameter & Mean \\
\hline Dry matter (\% natural matter) & 18.89 \\
Mineral matter (\% DM) & 11.22 \\
Total carbohydrates (\% DM) & 65.71 \\
Non-fiber carbohydrates (\%DM) & 14.00 \\
Neutral detergent fiber corrected for ashes and protein (\%DM) & 51.71 \\
Acid detergent fiber corrected for ashes and protein (\% DM) & 25.15 \\
Cellulose (\% DM) & 19.70 \\
Hemicelluloses (\% DM) & 25.56 \\
Lignin (\% DM) & 5.45 \\
Ethereal extract (\% DM) & 3.54 \\
Crude Protein (\% DM) & 19.56 \\
Neutral detergent insoluble protein (\% DM) & 5.19 \\
Acid detergente insoluble protein (\% DM) & 1.40 \\
\hline
\end{tabular}

$\mathrm{MS}=$ Dry matter.

In temperate climate cereals, for example wheat and barley carbon reserves are accumulated in the stem in the form of water soluble carbohydrates, mostly in the form of fructose (RUUSKA et al., 2008). However, assessing eight wheat genotypes with three fertilization levels $(0,100$ and $200 \mathrm{~kg} \mathrm{~N})$ in a greenhouse Valluru et al. (2011) observed the presence of fructose, sucrose and glucose. Probably, most of the non-fiber carbohydrate content ( $\hat{Y}$ $=14.00 \% \mathrm{DM}$ ) obtained in this study consists of 
soluble sugars in water. According Tylutki et al. (2008) the pool fermenting ruminal bacteria from non-fibrous carbohydrates using starch, pectin and sugar and grow faster than the pool of fermenting bacteria fibrous carbohydrates, since they can use ammonia or amino acids as nitrogen sources. Therefore, pastures that stimulate the growth pool fermenting ruminal bacteria from non-fibrous carbohydrates such as, for example, wheat BRS Tarumã $^{\circledR}$ increment the production of microbial protein and volatile fatty acids, favoring the ruminant response in larger quantity of meat, milk and / or wool per animal per hectare. Encouraging the propionate production decreases methane generation (VAN SOEST, 1994). According to Tedeschi et al. (2015) the production of sustainably ruminants, require identifying efficient animals, feeding systems and technologies that improve nutrient use efficiency.

The pastures are an energy source mainly in the form of carbohydrates: sugars, starch, pectin, cellulose and hemicellulose, a small amount of ether extract (Table 1) and more protein, with the latter nutrient must be in sufficient quantity to stimulate the physiological functioning of the rumen, as well as protein synthesis of tissue and metabolized products. However, according to Fox et al. (2004) the excess crude protein in the diet increases energy directed for maintenance, due the energy needs to convert ammonia into urea for this to be eliminated in the urine. CP content, NDIP and ADIP found in BRS Tarumã ${ }^{\circledR}$ grazing can help to reduce protein sources in the concentrate, because the ADIP content whose portion is unavailable at the rumen microflora and to the host is very small, this way there may be a decrease in production costs, since the protein sources are generally outside at rural company.

The content of mineral matter scanned in grasslands BRS Tarumã ${ }^{\circledR}$ are considered high, so that it is recommended in future studies performing fractionation of the mineral elements, so that the mineral supplements correct possible unbalances.
Besides its importance as mineral feed Hentz et al. (2014) state that for understanding the cycling of nutrients in crop-livestock integration system it is necessary to know the crop residues that remain on the soil surface, which constitute an important reserve of nutrients whose availability can be fast and intense, or slow and gradual according to the interaction between the climate factors, mainly precipitation and temperature, macro and microbiological activity and soil quality and quantity of waste.

The variable number of spikes per square meter, number of grains per spike, thousand grain weight, hectoliter weight and grain yield (Table 2) did not differ $(\mathrm{P}>0.05)$ between treatments. The first recommendation for farmers producing bread making wheat is to avoid excess $\mathrm{N}$ application beyond that necessary to optimize the yield and economic return (BLANDINO et al., 2015). The same authors reported that high levels of residual $\mathrm{N}$ in the soil, besides reducing the absorption rate of the $\mathrm{N}$, suggest divide the $\mathrm{N}$ applications and reduce the amount applied to the stem lengthening phase, to maintain a high yield.

During filling of the grains, there are two sources of nitrogen to the plant, $\mathrm{N}$ absorbed from the soil and the $\mathrm{N}$ remobilized from vegetative tissues (TA; WEILEND, 1992). The same authors using nitrogen remobilization marked to measure the rate of $\mathrm{N}$ into the field, in maize, they observed that the leaves and stems provide about $45 \%$ of the $\mathrm{N}$ remobilized during the grain filling while the roots have contributed around $10 \%$, therefore, the nutrients absorbed by the roots are not sufficient to provide required grain filling. Del Molino (1992) observed in wheat after anthesis, the grains are the main drain to $\mathrm{N}$ of leaves, thus leaf senescence during grain filling is very important for production.

Teixeira Filho et al. (2014) concluded that treatment in which nitrogen was applied at the beginning of the cycle (tillering) stimulated plants to increase the number of spikelets and, 
consequently, the number of grains per spike. The same authors report that the late application of $\mathrm{N}$ might be interesting to improve these components of yield. Therefore, it is understood that the nitrogen fertilization on wheat must be fractioned in various applications.

Table 2. Mean values and regressions wheat production survey parameters dual purpose handled with different levels of nitrogen fertilization (LNF) and grazed.

\begin{tabular}{|c|c|c|c|c|c|c|}
\hline \multirow{2}{*}{ Parameter } & \multirow{2}{*}{ Statistics } & \multicolumn{5}{|c|}{ Nitrogen fertilization levels $\left(\mathrm{Kg} \mathrm{ha}^{-1}\right)$} \\
\hline & & $\mathbf{0}$ & 75 & 150 & 225 & 300 \\
\hline \multirow{2}{*}{ Ears per metro ${ }^{2}$} & Mean & 737 & 814 & 795 & 715 & 746 \\
\hline & Regression & \multicolumn{5}{|c|}{$\hat{Y}=761.40$} \\
\hline \multirow{2}{*}{ Spike length $(\mathrm{cm})$} & Mean & 3.51 & 3.70 & 4.17 & 4.03 & 4.18 \\
\hline & Regression & \multicolumn{5}{|c|}{$\hat{\mathrm{Y}}=3.58+0.002 * \mathrm{LNF}\left(\mathrm{P}=0.0017 ; \mathrm{r}^{2}=43.13\right)$} \\
\hline \multirow{2}{*}{ Number of grains per spike } & Mean & 16.40 & 16.90 & 18.48 & 18.08 & 17.76 \\
\hline & Regression & \multicolumn{5}{|c|}{$\hat{\mathrm{Y}}=17.52$} \\
\hline \multirow{2}{*}{ Thousand grain weight } & Mean & 25.83 & 27.42 & 26.20 & 26.40 & 27.21 \\
\hline & Regression & \multicolumn{5}{|c|}{$\hat{Y}=26.63$} \\
\hline \multirow{2}{*}{ Hectolitre weight } & Mean & 72.30 & 71.77 & 73.47 & 74.62 & 74.47 \\
\hline & Regression & \multicolumn{5}{|c|}{$\hat{Y}=73.33$} \\
\hline \multirow{2}{*}{ Layering $(\%)$} & Mean & 8.33 & 32.50 & 60.00 & 44.17 & 69.17 \\
\hline & Regression & \multicolumn{5}{|c|}{$\hat{\mathrm{Y}}=16.16+0.17 * \operatorname{LNF}\left(\mathrm{P}=0.0001 ; \mathrm{r}^{2}=64.48\right)$} \\
\hline \multirow{2}{*}{ Production $\left(\mathrm{kg} \mathrm{ha}^{-1}\right)$} & Mean & 3,112 & 3,783 & 3,806 & 3,400 & 3,579 \\
\hline & Regression & \multicolumn{5}{|c|}{$\hat{Y}=3.536$} \\
\hline \multirow{2}{*}{ Residue $\left(\mathrm{kg} \mathrm{ha}^{-1}\right)$} & Mean & 4,460 & 7,216 & 6,884 & 6,325 & 8,018 \\
\hline & Regression & \multicolumn{5}{|c|}{$\hat{\mathrm{Y}}=5,335.90+8.30 * \operatorname{LNF}\left(\mathrm{P}=0.0081 ; \mathrm{r}^{2}=32.98\right)$} \\
\hline
\end{tabular}

Yang et al. (2000) observed that the heavy nitrogen fertilization delayed senescence wheat resulting in slow filling grains and low harvest index. The leaves contribute with most of the nitrogenous substrates for grain filling, increasing the total concentration of foliar amino acids, particularly aspartate and glutamate (NAKASATHIEN et al., 2000).

Comparing conventional wheat grain production systems (chemical fertilizer) and agro ecological (swine manure) on crop-livestock integration system in Santa Catarina Paiano et al. (2014) found that 1,000 BRS Tarumã ${ }^{\circledR}$ grains weighed around 24 grams and test weight (TW) obtained was more than 74 grams. The determination of TW lets you sort the wheat grains into three categories, according to rules published by the Ministério da Agricultura
(BRASIL, 2001): Type 1 with a minimum 78 of TW, Type 2 with a minimum of 75 of TW and Type 3 with a minimum 70 of TW. In order that wheat achieves greater financial remuneration in the Brazilian market it is needed to reach the classification type 1. However, in the states of Rio Grande do Sul, Santa Catarina and Paraná, near and during the harvest of cereals and oilseeds winters, they are often affected by weather which acts depreciating the quality of wheat grain. The average hectolitre weight obtained in this experiment $(\hat{Y}=73.33)$ is derived from sample taken after wind and rain, whose edaphoclimatic factors made wheat lodging.

Evaluating four levels of nitrogen fertilization $\left(0,60,120\right.$ and $\left.180 \mathrm{~kg} \mathrm{~N} \mathrm{ha}^{-1}\right)$ in an experiment conducted in the city of Marechal Cândido Rondon - PR Ramella et al. (2015) found increasing 
linear effect $(\mathrm{P}=0.01)$ for weight of 1,000 grains (variation between 31 and 35 grams) and for grain production (range between 700 and $1000 \mathrm{~kg}$ of grain per hectare). Nitrogen fertilization changed the spike length $(\mathrm{P}=0.0017)$, showing that there was a growth of ears, but not fertile flowers, diverging from the results reported by Whingwiri and Kemp (1980), that the application of nitrogen in one dose was held in the period spikelet terminal resulting in a greater number of fertile flowers (flowers that will establish grains) and consequently high yield.

For the variable lodging there was linear increasing $(\mathrm{P}=0.0001)$ demonstrating the susceptibility of the crop to high doses of nitrogen. However, it is believed that in this study the lodging has occurred by edaphoclimatic factors at the end of grain filling. In a study conducted by Espindula et al. (2010) with the cultivar Pioneer wheat, they found susceptibility to lodging due to the splitting of $\mathrm{N}$ rates, and can be explained by excessive vegetative growth causing nutritional imbalance, low stalk strength, mass of spikes and adverse climatic factors among others.

Nitrogen also influenced linearly $(\mathrm{P}=0.0081)$ the straw left after harvest of BRS Tarumã ${ }^{\circledR}$, which may allow at least four advantages to the subsequent culture: 1st release of nutrients; 2nd lower incidence of undesirable plants; 3rd lower evapotranspiration; and 4th minimize rain and / or wind erosion, whose benefits are essential for maintenance of direct planting systems on straw. In addition to the virtues mentioned of the straw it is important to mention the work done by Assmann et al. (2014) in the city of Pato Branco - PR, with dual purpose wheat in crop-livestock integration system, which concluded that the use of grazing animals accelerate the recycling of nutrients through excrement.

The increase in levels of soil organic matter and improving soil physical quality with the introduction of pastures in agricultural areas with adequate levels of fertility indicate that Integrated
Systems of Agricultural Production has the potential to reduce the environmental impact of production activities, to reduce emissions of greenhouse gases, with consequent increase in stability of production of annual crops and improved utilization of water and other nutrients (FRANCHINI et al., 2010).

\section{Conclusion}

The application of nitrogen fertilization on wheat dual purpose grazed before the spikelet terminal and anthesis stages does not influence on grain yield variables.

Nitrogen fertilization on wheat double purpose should be fractionated at tillering and after each grazing increasing the remobilization rate of nitrogen by the culture.

\section{Acknowledgements}

The authors thank Librelotto Farm, especially Mr. Ivonei Sandro Librelotto and Bussanello Family, for stimulating the research and not measuring efforts for the execution of the activities.

\section{References}

ASSMANN, T. S.; BORTOLLI M. A. de; ASSMANN, A. L.; SOARES,A.B.; PITTA, C. S.R.;FRANZLUEBBERS, A. J.; GLIENKE, C. L.; ASSMANN, J. M. Does cattle grazing of dual-purpose wheat accelerate the rate of stubble decomposition and nutrients released? Agriculture, Ecosystems and Environment, Amsterdam, v. 190 , n. 1 , p. $37-42,2014$.

BLANDINO, M.; MARINACCIO, F.; VACCINO, P.; REYNERI, A. Nitrogen fertilization strategies suitable to archive the quality requirements of wheat for biscuit production. Agronomy Journal, Madison, v. 107, n. 4, p. 1584-1594, 2015.

BRASIL. Instrução normativa $n^{\circ} 7$, de 15/08/2001. Regulamento técnico de identidade e qualidade do trigo. Ministério da Agricultura, Pecuária e Abastecimento. Diário Oficial [da] União, Brasília, 21 ago. 2001, Seção 1, p. 33-35. 
CARVALHO, P. C. de F.; MORAES, A.; PONTES, L. S.; ANGLINOMI, I.; SULE, R. M.; BATTELLO, C. Definições e terminologias para sistemas integrados de produção agropecuária. Revista Ciência Agronômica, Fortaleza, v. 45, n. 5, p. 1040-1046, 2014.

CARVALHO, P. C. de F.; TRINDADE, J. K.; MEZZALIRA, J. C.; POLI, C. H. E. C.; NABINGER, C.; GENRO, T. C. M.; GONDA, H. L. Do bocado ao pastoreio de precisão: compreendendo a interface planta-animal para explorar a multi-funcionalidade das pastagens. Revista Brasileira de Zootecnia, Viçosa, MG, v. 38, p. 109-122, 2009. Suplemento Especial.

COMISSÃO SUL-BRASILEIRA DE PESQUISA DE TRIGO - CSBPT. Reunião da Comissão Sul-Brasileira de pesquisa de trigo e triticale. Passo Fundo: [s.n], 2004. $86 \mathrm{p}$.

DEL MOLINO, M. Relationship between wheat grain protein percentage and grain yield plant growth and nutrition at authesis. Journal of Plant Nutrition, New York, v. 15, n. 2, p. 169-178, 1992.

ESPINDULA, M. C.; ROCHA, V. S.; SOUZA, M. A.; GROSSI, J. A. S.; SOUZA L. T. Doses e formas de aplicação de nitrogênio no desenvolvimento e produção da cultura do trigo. Ciência e Agrotecnologia, Lavras, v. 34, n. 6, p. 1404-1411, 2010.

FOX, D. G.; TEDESCHI, L. O.; TYLUTKI, T. P.; RUSSELL, J. B.; VAN AMBURGH, M. E.; CHASE, L. E.; PELL, A. N.; OVERTON, T. R. The Cornell net carbohydrate and protein system model for evaluating herd nutrition and nutrient excretion. Animal Feed Science and Technology, Amsterdam, v. 112, n. 1, p. 2978, 2004.

FRANCHINI, J. C.; DEBIASI, H.; WRUCK, F. J.; SKORUPA, L. A.; WINK, N. N.; GUISOLPHI, I. J.; CAUMO, A. L.; HATORI, T. Integração lavoura pecuária: alternativa para diversificação e redução do impacto ambiental do sistema produtivo no Vale do Rio Xingu. Londrina: EMBRAPA Soja, 2010. 20 p.

HENTZ, P.; CARVALHO, N. L.; LUZ, L. V.; BARCELLOS, A. L. Ciclagem de nitrogênio em sistemas de integração lavoura-pecuária. Ciência e Natura, Santa Maria, v. 36, n. 2, p. 663-676, 2014.

LUPATINI, G. C.; RESTlE, J.; CERETTA, M.; LONDERO, E.; RENE, H. Avaliação da mistura de aveia preta e azevém sob pastejo submetida a níveis de nitrogênio. I - produção e qualidade de forragem. Pesquisa Agropecuária Brasileira, Brasília, v. 33, n. 11, p. 1939-1943, 1998.
MEINERZ, G. R.; OLIVO, C. J.; FONTANELI, R. S.; AGNOLIN, C.A.; HORST, T.; BEM, C. M. Produtividade de cereais de inverno de duplo propósito na depressão central do Rio Grande do Sul. Revista Brasileira de Zootecnia, Viçosa, MG, v. 41, n. 4, p. 873-882, 2012.

NAKASATHIEN, S.; ISRAEL, D. W.; GIESLER, R. F.; KWANYUEN, P. Regulation of seed protein concentration in soybean by supra-optimal nitrogen supply. Crop Science, Madison, v. 40, n. 5, p. 1277-1284, 2000.

PAIANO, D.; NANTES, C. L.; KRAHL, G.; TUBIN, J. S. B.; CONTE, R. A.; PIVO, J. C. D.; FERRAZ, S. M.; BARETTA, D. Digestibilidade do grão de trigo de duplo propósito, cultivar BRS Tarumã, produzido em sistema agroecológico ou convencional para suínos. Semina: Ciências Agrárias, Londrina, v. 35, n. 4, p. 2767-2778, 2014. Suplemento.

RAMELLA, J. R. P.; LIBARDI, K. D. C.; CASTAGNARA, D. D.; MOTTIN, M. C.; SEIDEL, E. P.; OLIVEIRA, P. S. R. Agricultural yield components of dual purpose wheat cv. BRS Tarumã under cutting and nitrogen fertilization handlings. African Journal of Agricultural Research, Bloemfontein, v. 10, n. 8, p. 811820, 2015.

RODRIGUES, O.; TEIXEIRA, M. C. C.; CASTENARO, E. R. Manejo de trigo para alta produtividade. Revista Plantio Direto, Passo Fundo, v. 123, maio/jun., p. 19-24, 2011.

RUUSKA, S. A.; LEWIS, D. C.; KENNEDY, G.; FURBANK, R. T.; JENKINS, C. L. D.; TABE, L. M. Large scale transcriptome analysis of the effects of nitrogen nutrition on accumulation of stem carbohydrate reserves in reproductive stage wheat. Plant Molecular Biology, Dordrecht, v. 66, n. 1-2, p. 15-32, 2008.

SILVA, D. J.; QUEIROZ, A. C. de Análise de alimentos: métodos químicos e biológicos. Viçosa, MG: Editora UFV, 2002. $235 \mathrm{p}$.

SNIFFEN, C. J.; O'CONNOR, J. D.; VAN SOEST, P. J.; FOX, D. G.; RUSSELL, J. B. A net carbohydrate and protein system for evaluating cattle diets: II. Carbohydrate and protein availability. Journal of Animal Science, Champaign, v. 70, n. 11, p. 3562-3577, 1992.

SOUSSANA, J. F.; LEMAIRE, G. Coupling carbon and nitrogen cycles for environmentally sustainable intensification of grasslands and crop-livestock systems. Agriculture, Ecosystems and Environment, Amsterdam, v. 190, n. 1, p. 9-17, 2014.

STATISTICAL ANALYSIS SYSTEM - SAS. Statistical analysis system user's guide. Cary: Statistics Cary SAS Institute, 2001. 
TA, C. T.; WEILAND, R. T. Nitrogen partitioning in maize during ear development. Crop Science, Madison, v. 32, n. 2, p. 443-451, 1992.

TEDESCHI, L. O.; MUIR, J. P.; RILEY, D. G.; FOX, D. G. The role of ruminant animals in sustainable livestock intensification programs. International Journal of Sustainable Development \& World Ecology, Lancs, v. 22, n. 5, p. 452-465, 2015.

TEIXEIRA FILHO, M. C. M.; BUZETTI, S.; ANDREOTTI, M.; BENETT, C. G. S.; SA, M. E. Wheat nitrogen fertilization under no till on the low altitude Brazilian cerrado. Journal of Plant Nutrition, New York, v. 37, n. 11, p. 1732-1748, 2014.

TYLUTKI, T. P.; FOX, D. G.; DURBAL, V. M.; TEDESCHI, L. O.; RUSSELL, J. B.; VAN AMBURGH, M. E.; OVERTON, T. R.; CHASE, L. E.; PELL, A. N. Cornell net carbohydrate and protein system: a model for precision feeding of dairy cattle. Animal Feed Science and Technology, Amsterdam, v. 143, n. 1, p. 174-202, 2008.
VALLURU, R.; LINK, J.; CLAUPEIN, W. Natural variation and morpho-physiological traits associated with water-soluble carbohydrate concentration in wheat under different nitrogen levels. Field Crops Research, Amsterdam, v. 124, n. 1, p. 104-113, 2011.

VAN SOEST, P. J. Nutritional ecology of the ruminant. Ithaca: Cornell University, 1994. 476 p.

WHINGWIRI, E. E.; KEMP, D. R. Spikelet development and grain yield of the wheat ear in response to applied nitrogen. Australian Journal of Agricultural Research, Victoria, v. 31, n. 4, p. 637-647, 1980.

YANG, J.; ZHANG, J.; HUANG, Z.; ZHU, Q.; WANG, L. Remobilization of carbon reserves is improved by controlled soil-drying during grain filling of wheat. Crop Science, Madison, v. 40, n. 6, p. 1645-1655, 2000. 
